\title{
Gender-role Perception and Employment Status in the Self-efficacy of Women
}

\author{
By
}

\author{
${ }^{1}$ Dr. Sangeeta Rath and Aakankshya Mishra
}

\begin{abstract}
The effect of gender-role perception and employment status on the self-efficacy of women is examined. The study adopted a 2 (androgynous and sex-typed) X 2 (employed and unemployed) factorial design. One hundred and twenty women participated in the study. The sample consistsof 60 employed and 60 unemployed women. Both the groups of employed and unemployed women are categorized into androgynous and sex-typed on the basis of the median split of their scores on the measure of androgyny. The respondents of all the four groups are compared with respect to their level of perceived self-efficacy. The results indicate that androgynous women show better sense of efficacy compared to sextyped women. The results further indicate that employed women have better sense of selfefficacy than unemployed women.
\end{abstract}

Key Words: gender, employment, women, beahaviour, financial base

\section{Introduction}

The position and role of women in India have undergone tremendous changes. There was a time when women were only responsible for household affairs. They were expected to be docile, fragile, nurturing and submissive in interpersonal relationships. But now women work shoulder to shoulder with men. Women liberation movement and the greater participation of women in workforce have brought about some tangible changes. More and more women are pursuing higher education and are playing active roles outside their homes. Traditionally men were regarded as the breadwinners and women as the caretakers. But today women are no longer confined to the conventional role. The economic pressure (Lee \&Kanungo, 1984) and the psychological need of establishing one's own identity (Nieva, 1985) have encouraged women to pursue full time career and provide the family with financial assistance. This change in the status of women has positively affected their gender-role perception and self-efficacy. 
Gender-role refers to the social and behavioural norms that are considered appropriate for an individual of a given gender. Masculinity and femininity emerged as two key concepts in the gender issue. Generally it was believed that a person could either be masculine or feminine but not both. After 1960s researchers felt that a person could possess both masculine and feminine traits. This integration of both masculine and feminine elements in one person is referred to as androgyny.Androgynous individuals are independent, industrious and courageous, and at the same time they are nurturing, tender and expressive. They do not rely on gender as cognitive organizing principle. Their personality, therefore, combines both masculine and feminine elements (Bem,1974).

Androgyny has always been linked to positive psychological traits. A number of researches on androgyny indicate that androgynous individuals have greater flexibility and adaptability. These individuals show greater degree of mental health and indicate better work orientation and more effective coping strategies than sex-typed individuals. According to Choi (2004), androgynous people, in general, have higher self-concept, higher self-esteem, possess better problem solving skills and higher career self-efficacy. It is hypothesized that women with androgynous outlook are likely to possess higher sense of efficacy compared to sex-typed women. Since they can handle any work either of a male (work) or a female (family) properly with increased commitment and involvement, their sense of confidence and competence is more than sex-typed individuals.Androgynous individuals are described as flexible, adaptive, adjusted and liberated individuals (Bem\& Lenny, 1976). Androgyny greatly expands the range of behavior open to everyone, permitting people to cope more effectively with diverse situations.

Efficacy beliefs influence how people think, feel, motivate themselves and act (Bandura, 1992). The findings of diverse causal tests, in which efficacy beliefs are systematically varied, are consistent in showing that such beliefs contribute significantly to human motivation and attainment. Self-efficacy refers to the belief that one has complete control over his/her own life.It can be regarded as a self-confident view of one's capability to deal with certain life stressors. It is a can do cognition which mirrors a sense of control over one's environment. It is the estimate of one's own capability to overcome certain difficulties and do certain tasks.If a person is confident that he/she can deal with a given situation he/she is more inclined towards doing the same.Women who take up jobs have to manage multiple roles. Ozer (1992) evinced that the sense of efficacy in managing dual roles contributes to positive psychological traits. Because of this balancing system, working women manifest better mental health and higher sense of efficacy than non-working women. It is assumed that in this study employed women will show higher sense of efficacy than that of unemployed women.

\section{Method}

The objective is of the present investigation is to find out the effect of sex-role orientation and employment status on the sense of efficacy of women. Respondents 
The sample consists of one hundred and twenty women(sixty employed and sixty unemployed women). They are all educated and their minimum qualification is fixed at graduation. The age range of the respondents varies from 30-45 years and their average age is 36.41 years $(\mathrm{SD}=3.24)$. All the participants have middle socio-economic status and are married.

\subsection{Measures}

The present investigation has employed two standardized measures to examine the hypotheses.

Measure of Androgyny: Sahoo Sex Role Inventory is used as a measure of androgyny. Although Bem's Sex Role Inventory (BSRI) is often used as a measure of androgyny, recent concern with cultural parameters and relevance has prompted some considerations. While many items may have their stereotypic nature across cultures, it is possible that some items may be indigenously masculine or alternatively feminine. This possibility raises the requirement of developing and validating a sex role inventory relevant in Indian socio-cultural context.

Sahoo (1990) developed a culturally valid measure of androgyny. For the development and validation of the scale, Sahoo's Sex Role Inventory (SSRI) followed similar format of BSRI. However, due care was given to include some items that appeared relevant in India. The SSRI includes 20 masculine items, 20 feminine items and 20 filler items. Bem's masculine items like masculinity, leadership, and strong personality are retained in the SSRI. Similarly, Bem's feminine items like tender, affectionate, loves children, flatterable are also found in SSRI. However, masculine items like progressive, realistic, energetic and feminine items like mild, charming and soft-hearted, are new entrants in the SSRI. This change is conceivable in terms of cultural differences.

The administration and scoring of SSRI is similar to that of BSRI. The SSRI presents 60 items in a random order. Respondents are asked to indicate on a 7-point scale the extent to which each descriptor is characteristic of her or him. At the time of scoring masculine, feminine and the filler items are considered separately. The sum of endorsement rating of an individual across masculine traits indicates his or her masculinity score. Similarly, the sum of endorsement rating across feminine traits indicates femininity score.Gap between femininity and masculinity score indicate genderrole perception of an individual. Greater the gap, more sex-typed the individual is. The lower the gap, higher is the androgynous characteristics.

Measure of Self-efficacy: A culturally adapted scale of generalized self-efficacy is used. This scale was developed by Wegner, Schwarzer and Jerusalem (1981). The scale presents ten statements representing a situation. Respondents are asked to indicate the strength of their belief of execution on a four point scale where 1 indicates "Not at all true" and 4 denotes "Exactly true". Some of the items include: (a) always manage to solve difficult problems if I try hard enough; (b) If someone opposes me, I can find means and ways to get what I want; (c) It is easy for me to stick to my aims and accomplish my goals. The sum of scores across items is the generalized self-efficacy score.

In addition, a measure of domain-specific self-efficacy is employed. Schwarzer (1981) has developed a number of domain specific or situation-specific scales that are designed 
to predict health behaviour. In similar line, Sahoo (1997) has developed a domainspecific scale to predict self-efficacy in family/work context. The scale represents ten obstacles that are likely to be encountered in family/work context. Respondents are asked to indicate the certainty of the belief on a 7 point scale in executing family/work obligation. The scale ranges from "Not at all confident" to "Very confident". The sum of scores across items is domain specific self-efficacy score.

\subsection{Procedure}

The study involved a 2 (androgynous versus sex-typed) X 2 (employed versus unemployed) factorial design. One hundred and twenty women(sixty employed and sixty unemployed) were given Sahoo Sex Role Inventory. The respondents of both the groupswere categorized into androgynous and sex-typed group on the basis of the median split of their scores on the measure of androgyny. The respondents of all the four groups were compared on basis of their level of self-efficacy.

RESULTS

NOTE: GRP stands for Gender Role Perception

ES stands for Employment Status

Table-1: Summary of the Analysis of Variance Performed on Generalized and Domain-specific Self-efficacy Scores of Respondents.

\begin{tabular}{|c|l|l|c|c|}
\hline $\begin{array}{c}\text { Self-efficacy } \\
\text { Dimensions }\end{array}$ & Sources & Df & MS & F \\
\hline Generalized & GRP & 1 & 19.44 & $180.97^{*}$ \\
Self-efficacy & ES & 1 & 3.50 & $32.60^{*}$ \\
& GRP X ES & 1 & .002 & .019 \\
& Error & 116 & .107 & \\
\hline Domain-Specific & GRP & 1 & 94.69 & $425.30^{*}$ \\
Self-efficacy & ES & 1 & 1.24 & $5.57^{*}$ \\
& GRP X ES & 1 & .408 & 1.83 \\
& Error & 116 & .233 & \\
\hline
\end{tabular}

$* \mathrm{P}<.05$

Table-2: Summary of the Mean Ratings and Standard Deviations of Generalized and Domain-specific Self-efficacyScores of Respondents.

\begin{tabular}{|c|c|c|c|c|c|}
\hline $\begin{array}{l}\text { Self-efficacy } \\
\text { Dimensions }\end{array}$ & Groups & $\begin{array}{l}\text { And } \\
M\end{array}$ & SD & $\begin{array}{l}\text { Sex-typed } \\
\text { SD }\end{array}$ & $\begin{array}{c}\text { Combined } \\
\mathrm{M}\end{array}$ \\
\hline $\begin{array}{l}\text { Generalized } \\
\text { Self-efficacy }\end{array}$ & $\begin{array}{l}\text { Employed } \\
\text { Unemployed } \\
\text { Combined }\end{array}$ & $\begin{array}{l}3.39 \\
2.58 \\
2.99\end{array}$ & $\begin{array}{l}.34 \\
.32\end{array}$ & $\begin{array}{c}3.04 \\
.41 \\
2.25 \\
.18 \\
2.64\end{array}$ & $\begin{array}{l}3.33 \\
2.41\end{array}$ \\
\hline $\begin{array}{l}\text { Domain- } \\
\text { Specific } \\
\text { efficacy }\end{array}$ & $\begin{array}{l}\text { Employed } \\
\text { Unemployed } \\
\text { Combined }\end{array}$ & $\begin{array}{l}5.86 \\
4.20 \\
5.03\end{array}$ & $\begin{array}{l}.48 \\
.43\end{array}$ & $\begin{array}{c}5.78 \\
.46 \\
3.88 \\
.50 \\
4.83\end{array}$ & $\begin{array}{l}5.82 \\
4.04\end{array}$ \\
\hline
\end{tabular}


The Analysis of Variance (ANOVA) performed on generalized and domain-specific self-efficacy indicates significant effect for gender-role perception, $\underline{\mathrm{F}}(1,116)=180.97, \mathrm{P}$ $<.05$ and $\underline{\mathrm{F}}(1,116)=425.30, \mathrm{P}<.05$ respectively (see Table- 1$)$. As shown by Table-2, androgynous women report better sense of generalized and domain-specific self-efficacy than sex-typed women $(\underline{M}=2.99 \& 2.64$ and $\underline{\mathrm{M}}=5.03 \& 4.83$ respectively). The Analysis of Variances performed on generalized and domain-specific self-efficacy also indicate significant effect for employment status, $\underline{\mathrm{F}}(1,116)=32.60, \mathrm{P}<.05$ and $\underline{\mathrm{F}}$ $(1,116)=5.57, \mathrm{P}<.05$ respectively. Table- 2 indicates that employed women report better sense of generalized and domain-specific self-efficacy compared to unemployed women $(\underline{\mathrm{M}}=3.33 \& 2.41$ and $\underline{\mathrm{M}}=5.82 \& 4.04$ respectively $)$.

\section{Discussion}

The present empirical investigation examines the impact of gender-role perception and employment status on the sense of self-efficacy of women. The above findings clearly show that androgynous women possess better sense of generalized and domain-specific self-efficacy compared to sex-typed women.

Androgyny represents an ideal of human functioning, blending the best of both masculinity and femininity. Androgynous individuals are able to engage in masculinefeminine or a blend of these characteristics depending upon what is appropriate for a specific situation (Bem, 1975). They can remain sensitive to the changing constraints of the situation and engage in behavior that seems most effective at the point of time regardless of its stereotypeas appropriate for one sex or the other. In other words, for the androgynous individuals, the traits of masculinity and femininity simply do not exist. When the artificial constraint of gender is eliminated, they show broader range of social skills and competencies, as a result of which their sense of efficacy is higher than sextyped women. Mueller and Dato-On (2007) examined the influence of gender-role orientation on entrepreneurial self-efficacy. They found that androgynous orientation is associated with higher level of entrepreneurial self-efficacy than a sex-typed orientation.

The present study also reveals that employed women have better sense of generalized and domain specific self-efficacy than unemployed women.In general, employment, marriage and parenthood are associated with good mental and physical health, among both men and women. Verbrugge (1983) found that employed married parents tend to be the healthiest, whereas people with none of these roles tend to have the poorest health. Stewart and Malley (in press) suggested that involvement in a multiplicity of roles has been found to be associated with lower level of stress and higher levels of physical and mental health. Studies have shown higher level of life satisfaction (Stewart \& Salt, 1981) and self-esteem (Pietromanaco, Manis\&Frohardt-Lane, 1984) among women who occupy the three roles of wife, mother and paid worker effectively compared to women who occupy fewer roles. A wide variety of well-controlled studies show thatemployed women are higher on self-esteem (Winefield\&Tiggemann, 1990; Messias et al, 1997; Mary \& Good, 2005) and well-being (Bartley et al, 1992; Rao, 2003). They have strong ability, committed interest and better psychological health (Donelson and Gullahson, 1977). All of these positive characteristics enhance their self-efficacy and self-esteem. In a recent study conducted by Sadeghi and Vasudeva (2006) it was found that 
professionally employed women significantly scored higher on self-efficacy and selfesteem than unemployed women.

Women's employment appears to have positive effect. The independent financial base supplied by employment provides women with an increased sense of competence, gives women more power within the marriage, and increases their influence in decision making ( Blood, 1965).

\section{References}

Bandura, A. (1992). Exercise of personal agency through self-efficacy mechanism. In R. Washington, DC: Hemisphere. Schwarzer (Ed.), Self-efficacy: Thought control of action (pp. 3-38).

Bartley, M., Popay, J.,\&Plewis, I. (1992). Domestic conditions, paid employment and women's experienceof ill-health. Sociology of Health and Illness, 14: 313-343. Bem, S. L. (1974). The measurement of psychological androgyny.Journal of Consulting and Clinical Psychology, 31, 634-643.

Bem, S. L. (1975). Sex-role adaptability: One consequence of psychological androgyny. Journal of Personality and Social Psychology, 31, 634-643.

Bem, S. L., \& Lenny, E. (1976).Sex-typing and avoidance of cross-sex behavior.Journal of Personality and Social Psychology, 33, 48-54.

Blood, R.O. Jr.(1965). Long range causes and consequences of the employed married woman. Journal of the Marriage and Family, 27(1), 43-47.

Choi, N. (2004). Sex-role group differences in specific, academic and general self-efficacy.The Journal of Psychology: Interdisciplinary and Applied, Vol. 138, 2, 149-159.

Donelson, E., Gullahorn, JE. (1977).Women: A psychological perspective. New York, John Wiley and Sons.

Lee, M. D., \&Kanungo, R. N. (1984).Work and personal life coordination in a changing society. In M. D. Lee \& R. N. Kanungo (Eds.), Management of work and personal life: $\quad$ Problems and oppurtunities, (pp. 1-9). New York: Praeger.

Mary, D., Good, G. (2005).Women and mental health of cache. www.un.org/womenwatch/daw/csw/mental.htm.

Messias, D. K. H., Im, E., Page, A., Regev, H., Spiers, J., Yoder, L., \&Meleis, A. I. (1997).Defining and redefining work: Implications for women's health. Gender \& Society, 11(3), 296-323.

Mueller, S.L., and Dato-On, M.C.(2007).Gender-role orientation as a determinant of Vol.13, No.1 (2008) 3-20.

Nieva, V. (1985).Work and family linkages.In L. Larwood, A. Stromberg \& B. Gutek (Eds.), Women and work, (Vol. 3, PP. 162-191). Newbury Park, CA: Sage.

Ozer, E. M. (1992).Meaning work and family: The effect of child care on perceived self-efficacy and the psychological health of the new working mothers. Unpubished doctoral dissertation.Stanford University, Stanford, CA.

Park, J. (2000). The effect of multiple roles of South Korean married women professors: Role changes and the factors which influence potential role gratification and strain. A Journal of Research 2000. Vol. 43, Issues 7-8, 571-591. 
Pietromonaco, P. R., Manis, J., \&Frohardt-Lane, K. (1984).Psychological consequences of multiple social roles. Paper presented at the meeting of American Psychological Association, Toronto.

Rao, K. (2003).Coping and subjective wellbeing in women with multiple roles.International Journal of Social Psychiatry,49(3):175-184.

Sadeghi, I. A., and Vasudeva, p. (2006). Self-efficacy and Self-esteem: A comparative study of employed and unemployed married women in Iran. The German Journal of Psychiatry, 9, 111-117.

Sahoo, F. M. (1990). Sahoo Sex-role Inventory (SSRI), Unpublished report, Psychology

Department, Utkal University, Bhubaneswar, India.

Sahoo, F. M. (1997). The measure of domain-specific self-efficacy.Unpublished report,

Psychology Department, Utkal University, Bhubaneswar, India.

Schwarzer, R. (Ed.) (1981). Measurement of Perceived Self-efficacy.Berlin: Free University.

Stewart, A. S., \&Malley, J. E. (in press). Role combination in women in the early adult years: worker: $O n$

Mitigating agency and communication. In F. Crosby (Ed.), Spouse, parent,

Stewart, A. S., \& Salt, P. (1981).Life stress, life styles, depression and illness in adult women.

Journal of Personality and Social Psychology, 40, 1063-69.

Verbrugge, L. (1983). Multiple roles and physical health of women and men.Journal of Health and Social Behaviour, 24, 16-30.

Wegner, M. Schwarzer, R. \& Jerusalem, M. (1981).Generalized self-efficacy.In R. Schwarzer

(Ed.).Measurement of Perceived self-efficacy. Berlin: Free University.

Winefield,AH.,Tiggemann, M. (1990). Employment status and psychological well-being: A longitudinal study. Journal of Applied Psychology, 75: 455-459. 
